$06 ; 12$

\title{
Графен как сенсибилизирующая добавка в энергонасыщенную соль кобальта для усиления воздействия сильноточного электронного пучка
}

\author{
(C) Г.Г. Савенков ${ }^{1}$, В.А. Морозов ${ }^{2}$, М.А. Илюшин ${ }^{1}$, В.М. Кац ${ }^{2}$ \\ ${ }^{1}$ Санкт-Петербургский технологический институт (Технический \\ университет), Санкт-Петербург, Россия \\ ${ }^{2}$ Санкт-Петербургский государственный университет, Санкт-Петербург, \\ Россия \\ E-mail: sav-georgij@yandex.ru
}

Поступило в Редакцию 10 января 2018 г.

Исследуется влияние на чувствительность энергонасыщенной соли кобальта к воздействию сильноточного электронного пучка наносекундной длительности добавок графена. Энергонасыщенный композит изготавливался путем ультразвукового смешения 80 mass \% аммоната кобальта и 20 mass \% графена. Показано, что использование графена в качестве сенсибилизирующей добавки в энергонасыщенный композит снижает энергетические параметры электронного пучка и повышает энергетические характеристики и скорость горения энергонасыщенных материалов.

\section{DOI: 10.21883/PJTF.2018.12.46289.17204}

Одним из перспективных направлений, связанных с повышением скорости горения смесевых энергонасыщенных материалов (ЭНМ) и быстрым переходом горения в детонацию, является применение наноразмерных компонентов в системе горючее-окислитель [1]. В первую очередь применение таких составляющих ЭНМ объясняется резким увеличением эффективной поверхности контактирующих компонентов смеси, их химической активности [2] и скорости реакции между горючим и окислителем. Напомним, что в классических взрывчатых веществах (подкласс ЭНМ), состоящих, как правило, из атомов углерода, водорода, азота и кислорода, окислитель и горючее находятся в 
одной и той же молекуле, поэтому реакция между ними происходит с максимально возможной скоростью.

В работе [3] на основании предположения о том, что кристаллические взрывчатые вещества (BВ) являются полупроводниками, показано, что скорость их горения зависит от ширины запрещенной зоны: чем меньше ширина запрещенной зоны, тем выше скорость горения. Отсюда следует, что если создать смесевые ЭНМ (или ВВ как их подкласс) в виде проводников, у которых ширина запрещенной зоны равна нулю, а также использовать при этом наноразмерные компоненты, то можно получить максимальную скорость горения даже на зарядах с небольшими размерами и тем самым резко сократить время индукции перехода горения в детонацию.

Очевидно, что если добавлять проводящие добавки в ЭНМ (ВВ), то наибольшую эффективность получаемого энергонасыщенного композита (ЭНК), по крайней мере с точки зрения чувствительности к внешнему инициирующему импульсу, можно ожидать при электрофизических способах инициирования: высоковольтным разрядом [4], электрическим взрывом проводника [5], сильноточным электронным пучком наносекундной длительности [6].

Одним из таких перспективных материалов, обладающих указанными свойствами, который можно использовать в качестве добавок в ЭНМ, является двумерная аллотропная форма углерода - графен. Кроме того, что он обладает большой электропроводностью. Графен также по некоторым оценкам имеет аномально высокий коэффициент теплопроводности $\sim 5 \cdot 10^{3} \mathrm{~W} /(\mathrm{m} \cdot \mathrm{K})$ [7]. И наконец, можно отметить, что графен выгодно отличается от существующих достаточно доступных металлических (а значит, проводящих) нанопорошков, которые очень быстро пассивируются при хранении [8], отсутствием такой пассивации. Можно также отметить, что введение графена в нитрометан (жидкое ракетное топливо) снизило температуру зажигания и повысило скорость горения топлива [9].

Настоящая работа посвящена исследованию влияния на чувствительность энергонасыщенной соли кобальта (NCP) к воздействию сильноточного электронного пучка (СЭП) наносекундной длительности добавок графена.

Энергонасыщенный композит на основе аммината кобальта (перхлорат (5-нитротетразолато-N ${ }^{2}$ ) пентааминкобальта (III) с акцепторным заместителем (соединение NCP)) (плотность кристаллов NCP

Письма в ЖТФ, 2018, том 44, вып. 12 


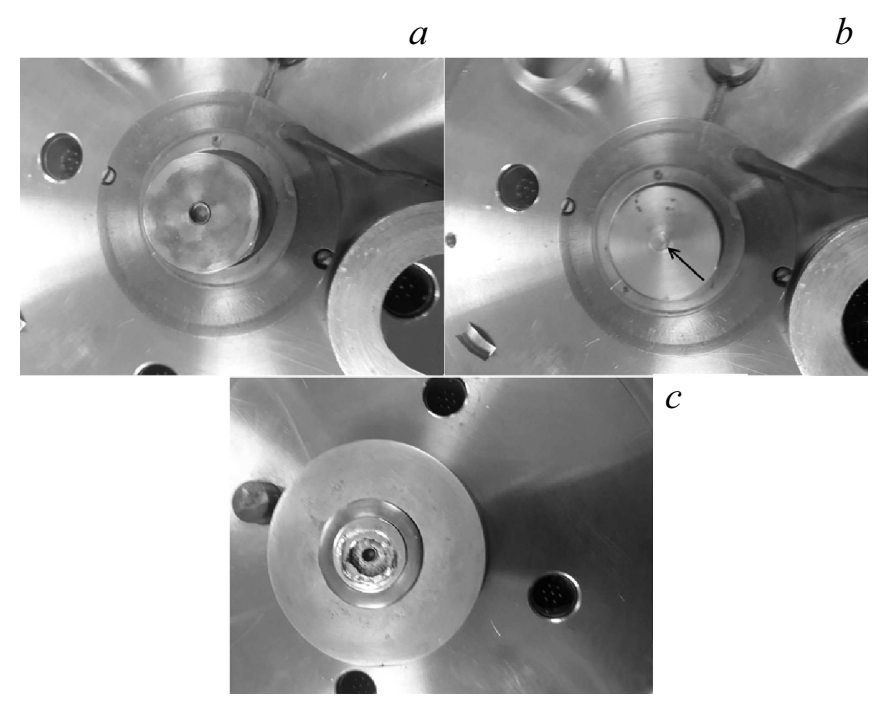

Рис. 1. Фотографии устройства для установки образца после проведения опытов: цвета побежалости $(a)$, отпечаток (указан стрелкой) на стальной подложке $(b)$ и колпачек с наполовину выгоревшим ЭНК $(c)$.

$\rho_{\text {exp }}=2.03 \mathrm{~g} / \mathrm{cm}^{3}$ ) изготавливался путем ультразвукового смешения $80 \%$ NCP и 20\% графена (приведены массовые доли), полученного с помощью самораспространяющегося высокотемпературного синтеза технического лигнина [10].

Полученный по указанной технологии ЭНК запрессовывался в колпачок глубиной $2 \mathrm{~mm}$ с внутренним диаметром $4.5 \mathrm{~mm}$. Масса запрессованного ЭНК составляла $38 \mathrm{mg}$, плотность $\rho_{c}=1.2 \mathrm{~g} / \mathrm{cm}^{3}$.

Схема облучения образца (ЭНМ) пучком в принципе аналогична схеме, приведенной в работах $[6,11-13]$. В качестве электронного ускорителя использовалась установка ГКВИ-300 [14]. Колпачок с исследуемым ЭНК помещался в стальное кольцо с внешним диаметром $30 \mathrm{~mm}$. Стальное кольцо устанавливалось на стальную подложку толщиной $2.2-2.5 \mathrm{~mm}$.

Длительность импульса тока на его полувысоте составляла $20-40 \mathrm{~ns}$, средняя энергия электронов в пучке $250 \mathrm{keV}$, расстояние между катодом и образцом $4 \mathrm{~mm}$, диаметр пучка $8 \mathrm{~mm}$. Эксперименты

Письма в ЖТФ, 2018, том 44, вып. 12 


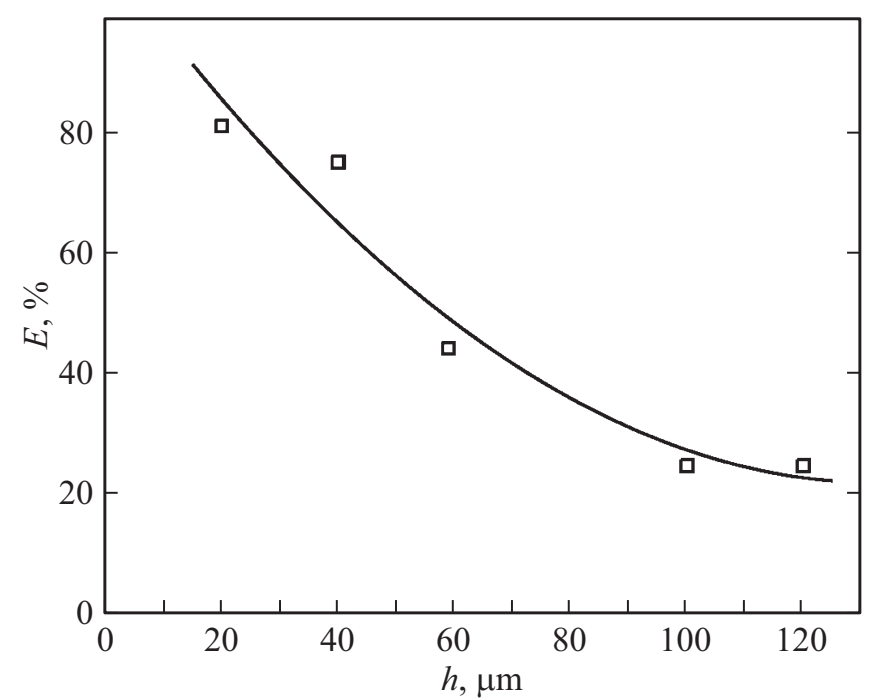

Рис. 2. Изменение энергии СЭП в зависимости от толщины алюминевой фольги.

проводились как с отсечкой (путем установки на кольцо алюминиевой фольги толщиной 20 или $40 \mu \mathrm{m}$ ) катодного факела (КФ) (т. е. в этом случае на образец действовал только электронный пучок), так и без отсечки (в этом случае на образец действовал СЭП + КФ). Пояснения понятия „катодный факел“ и его характеристики приведены в [6,12].

Действие СЭП (при отсечке КФ) на образцы с чистым NCP (без добавок графена) при плотности, равной плотности ЭНК, к возбуждению взрывчатых превращений (ВП) в образцах не приводило. Совместное действие СЭП+КФ приводило к возбуждению ВП (горению), и NCP в колпачке полностью выгорал, при этом на подложке отпечатка от колпачка не наблюдалось, т.е. можно полагать, что в этом случае происходило послойное горение образцов с малой скоростью.

Действие СЭП (при отсечке КФ путем установки на кольцо алюминиевой фольги толщиной $20 \mu \mathrm{m})$ на образцы из исследуемого ЭНК приводило к возбуждению ВП. При этом на кольце, в которое помещался колпачок с ЭНК, наблюдались цвета побежалости (рис. 1,a), а на 
стальной подложке - отпечаток глубиной $50 \mu \mathrm{m}$ (рис. $1, b$ ). Отметим, что в [12] при инициировании образца NCP (без добавок) совокупным воздействием СЭП + КФ на подложке также наблюдался отпечаток глубиной $50 \mu \mathrm{m}$, но в указанной работе масса образца составляла $54 \mathrm{mg}$, а плотность запрессованного образца $\rho_{\exp }=1.25 \mathrm{~g} / \mathrm{cm}^{3}$. Таким образом, в настоящей работе при инициировании с помощью СЭП (без КФ) образца NCP с добавкой 20 mass \% графена (с меньшими общей массой и плотностью) наблюдаются как более быстрый режим горения (вплоть до дефлаграционного горения), так и режим с более высокими энергетическими характеристиками. При этом величина внешнего инициирующего импульса в настоящей работе была существенно меньше.

Установка на стальное кольцо алюминиевой фольги толщиной $40 \mu \mathrm{m}$ приводила к тому, что ЭНК в колпачке выгорал наполовину (рис. 1,c), что свидетельствовало о невысокой энергии инициирующего импульса. В результате горение было неустойчиво и, как следствие, приводило к погасанию образца.

Действительно, эксперименты, проведенные с целью определения влияния толщины фольги на энергетические параметры пучка, показали, что при установке фольги толщиной $40 \mu \mathrm{m}$ энергия электронов пучка уменьшается на $\sim 25 \%$ (рис. 2 ).

Таким образом, полученные результаты свидетельствуют о возможности использования графена в качестве сенсибилизирующей добавки в энергонасыщенные материалы для снижения энергетических параметров сильноточного электронного пучка и повышения энергетических характеристик и скорости горения ЭНМ.

\section{Список литературы}

[1] Долгобородов А.Ю., Стрелецкий А.Н., Махов М.Н., Теселкин В.А., Гусейнов Ш.Л., Сторожсенко П.А., Фортов В.Е. // Хим. физика. 2012. Т. 31. № 8. C. $37-44$.

[2] Левданский В.В., Смолик И., Моравеи, И. // Инж.-физ. журн. 2010. Т. 83. № 2. C. 376-380.

[3] Гребёнкин К.Ф. // Письма в ЖТФ. 1998. Т. 24. В. 20. С. 1-4.

[4] Брагин В.А., Душенок С.А., Куликов В.Г., Савенков Г.Г., Семашкин Г.В. // Хим. физика. 2012. Т. 31. № 5. С. 57-64.

Письма в ЖТФ, 2018, том 44, вып. 12 
[5] Лукин А.А., Морозов В.А., Савенков Г.Г. // Физико-химические аспекты предельных состояний и структурных превращений в сплошных средах и технических системах. СПб.: Политехника, 2017. В. 1. С. 88-94.

[6] Лукин А.А., Морозов В.А., Рашковский С.А., Савенков Г.Г. // Хим. физика. 2015. T. 34. № 4. C. 69-75.

[7] Shahil K.M.F., Balandin A.A. // Nano Lett. 2012. V. 12. N 2. P. 861-867.

[8] Рогачёв А.С., Мукасьян А.С. // Физика горения и взрыва. 2010. Т. 46. № 3. C. 3-30.

[9] Sabourin J.L., Dabbs D.M., Yetter R. A., Dryer F.L., Aksay I.A. // ACS Nano. 2009. V. 3. N 12. P. 3945-3954.

[10] Возняковский А.П., Савкин Д.И., Калинин А.В., Шугалей И.В., Крутов С.М., Мазур А.С. // Экологическая химия. 2016. Т. 25. № 3. С. 132-137.

[11] Савенков Г.Г., Морозов В.А., Брагин В.А., Кач В.М., Лукин А.А. // ЖТФ. 2013. T. 83. B. 7. C. $96-99$.

[12] Савенков Г.Г,, Морозов В.А., Илюшин М.А., Оськин И.А., Брагин В.А., Козлов А.С. // ЖТФ. 2017. Т. 87. В. 11. С. 1701-1706.

[13] Савенков Г.Г., Морозов В.А., Персинен А.А., Оськин И.А., Брагин В.А., Лукин А.А. // Письма в ЖТФ. 2016. Т. 42. В. 17. С. 28-33.

[14] Морозов В.А., Савенков Г.Г., Брагин В.А., Каи, В.М., Лукин А.А. // ЖТФ. 2012. T. 82. B. 5. C. $129-134$. 